\title{
PERLAKUAN AKUNTANSI TRANSAKSI DANA PESERTA PRODUK TAKAFUL PENDIDIKAN PADA PT ASURANSI TAKAFUL KELUARGA CABANG BANJARMASIN
}

\author{
INES SARASWATI MACHFIROH \\ Jurusan Teknik Informatika, Politeknik Negeri Tanah Laut \\ Jl. A. Yani, km 06, Ds. Panggung, kec. Pelaihari, Kab. Tanah Laut, Kalimantan Selatan \\ e-mail: inessaraswati.m@gmail.com
}

\begin{abstract}
Abstrak
Asuransi pendidikan merupakan salah satu produk dari asuransi Keluarga (jiwa) yang mengandung unsur saving. Selain itu unsur preminya terdiri dari rekening tabungan peserta dan rekening dana tabarru', bagi hasilnya dilakukan sesuai dengan skim bagi hasil, dan sumber pembayaran klaim meninggal dunia diperoleh dari akumulasi rekening dana tabarru'para peserta. Klaim yang dapat diajukan peserta pada asuransi pendidikan terdiri dari klaim nilai tunai, klaim meninggal dunia, klaim habis kontrak, dan klaim tahapan manfaat.

Produk Takaful Pendidikan merupakan produk yang menawarkan tahapan manfaat pendidikan bagi penerima hibah (anak) mulai masuk TK, masuk SD, masuk SMP, masuk SMU sampai dengan Perguruan Tinggi. Perlakuan akuntansi pada produk Takaful Pendidikan untuk premi tahun pertama dialokasikan pada rekening kewajiban manfaat polis masa depan (dana tabarru') dan rekening dana pemegang polis unit link (tabungan peserta), untuk bagi hasil dibagikan sesuai dengan skim bagi hasil dan dicatat dalam rekening dana pemegang polis unit link (bagi hasil), dan untuk klaim tahun pertama hanya terdiri dari klaim nilai tunai dan klaim meninggal dunia. Dimana masing-masing jenis klaim tersebut akan mempengaruhi tahapan manfaat yang akan diterima peserta.
\end{abstract}

Kata Kunci: premi, klaim, tabarru'

\section{PENDAHULUAN}

Takaful Pendidikan merupakan salah satu produk individual yang mengandung unsur saving (tabungan) dan merupakan produk yang menawarkan tahapan manfaat pendidikan bagi penerima hibah (anak) mulai masuk TK, SD, SMP, SMU sampai dengan Perguruan Tinggi.

Dana peserta dalam produk Takaful Pendidikan akan dibagikan ke dalam dua rekening, yaitu rekening dana pemegang polisunit link (tabungan peserta) dan rekening kewajiban manfaat polis masa depan (dana tabarru'). Akuntansi dana peserta sangat dibutuhkan terutama dalam menginformasikan setiap transaksi yang berkaitan dengan 
dana peserta. Informasi tersebut dibutuhkan oleh pihak intern, seperti manajemen untuk pengambilan keputusan.

\section{TINJAUAN PUSTAKA}

\section{Asuransi Syariah}

Dalam PSAK No. 108 Paragraf 41 (Revisi Tahun 2009) menyatakan bahwa asuransi syariah adalah sistem menyeluruh yang pesertanya mendonasikan (mentabarru'-kan) sebagian atau seluruh kontribusinya yang digunakan untuk membayar klaim atas risiko tertentu akibat musibah pada jiwa, badan, atau benda yang dialami oleh peserta yang berhak.

\section{Dana Peserta dalam Asuransi Syariah}

Ghoni (2007:79-98) menjelaskan bahwa dana peserta dalam asuransi syariah merupakan kumpulan dana dari setiap premi yang dibayarkan oleh para peserta asuransi syariah. Dana peserta dalam asuransi syariah terdiri dari rekening dana tabarru' dan rekening tabungan peserta untuk produk yang mengandung unsur saving serta hanya terdiri dari rekening dana tabarru' saja untuk produk yang mengandung unsur nonsaving.

\section{Asuransi Pendidikan}

Sula (2004:636-638) Konsep dan Sistem Operasional menjelaskan bahwa asuransi pendidikan merupakan salah satu produk dari asuransi Keluarga (jiwa) dan produk individual yang mengandung unsur saving (tabungan), artinya premi yang disetorkan akan dibagi ke dalam dua rekening, yaitu rekening tabungan peserta dan rekening dana tabarru'.

Sholihah (2010:72) menjelaskan bahwa di dalam asuransi pendidikan peserta memiliki 4 kemungkinan, yakni kemungkinan masih hidup sampai masa kontrak berakhir, meninggal dunia selama masa kontrak berlangsung, dan kemungkinan peserta, penerima hibah maupun ahli warisnya meninggal dunia semua ditengah-tengah masa perjanjian serta kemungkinan peserta, penerima hibah, ahli waris maupun saudara kandung dari pesertanya meninggal dunia ditengah-tengah perjanjian.

Juhriah (2008:2) menjelaskan bahwa asuransi pendidikan terkenal sebagai produk yang menawarkan tahapan manfaat, tahapan ini akan diberikan saat penerima hibah (anak) mulai masuk TK, SD, SMP, SMU sampai dengan Perguruan Tinggi. 


\section{Perlakuan Akuntansi Asuransi Pendidikan}

Sula (2004:316) menjelaskan bahwa pencatatan akuntansi pada asuransi syariah lebih cenderung menganut cashbasis daripada accrualbasis dengan pertimbanganpertimbangan syari'i. Asuransi syariah sudah memiliki standar akuntansi, yaitu Pernyataan Standar Akuntansi Keuangan (PSAK) No. 108 Tahun 2009 sehingga asuransi pendidikan mengacu pada PSAK No. 108 Tahun 2009 khususnya yang berkaitan dengan akuntansi asuransi jiwa (Keluarga) syariah.

\section{METODE PENELITIAN}

\section{Studi Kasus}

Dalam penelitian ini dilakukan pendekatan studi kasus pada PT Asuransi Takaful Keluarga Cabang Banjarmasin, dimana lebih menekankan pada perlakuan akuntansi yang hanya meliputi pengakuan dalam pencatatan akuntansi dan penyajiannya dalam laporan keuangan. Data akuntansi hanya didasarkan pada data transaksi satu peserta pada tahun pertama, yaitu pada tanggal 30 April 2011 sebagai ilustrasi.

\section{HASIL DAN PEMBAHASAN}

\section{Perlakuan Akuntansi Transaksi Dana Peserta Produk Takaful Pendidikan pada PT Asuransi Takaful Keluarga Cabang Banjarmasin}

Berikut gambaran umum mengenai ilustrasi dan penjelasan studi kasusnya.

Tanggal 30 April 2010, Tn. Arif (nama samaran) mulai mengikuti program produk Takaful Pendidikan Takaful Keluarga untuk anaknya. Saat mengikuti program tersebut, Tn. Arif berusia 31 tahun sedangkan anaknya berusia 0 tahun. Anak yang diikutkan asuransi oleh Tn. Arif ditunjuk sebagai penerima hibah.

Masa perjanjian Tn. Arif selama 18 tahun yang berakhir pada tanggal 30 April 2028. Dari masa perjanjian yang selama 18 tahun tersebut, maka penerima hibah mendapatkan tahapan manfaat, yaitu saat masuk TK (tahun ke-6), masuk SD (tahun ke7), masuk SMP (tahun ke-13), masuk SMU (tahun ke-16) dan masuk PT (tahun ke-18). Premi yang dibayar oleh Tn. Arif pada ilustrasi ini sebesar Rp1.200.000,00 per tahun. Khusus untuk tahun pertama selain membayar premi yang sebesar Rp1.200.000,00 Tn. Arif juga harus membayar biaya polis sebesar Rp25.000,00 sehingga jumlah yang dibayarkan oleh Tn. Arif pada tahun pertama sebesar Rp1.225.000,00. Nilai tabarru' yang dikenakan oleh pihak Takaful ke Tn. Arif sebesar 8,6\% dari premi. 
Manfaat Takaful Awal (MTA) yang akan diperoleh Tn. Arif untuk ilutrasi ini sebesar Rp21.600.000,00. Apabila peserta meninggal dunia karena non-kecelakaan maka akan mendapatkan 50\% dari MTA sedangkan apabila peserta meninggal dunia karena kecelakaan maka akan mendapatkan $100 \%$ dari MTA.

Di samping itu pihak Takaful menetapkan total biaya pengelolaan untuk ilustrasi ini sebesar $75 \%$ dari premi tahun pertama. Asumsi tingkat investasi untuk produk ini sebesar 7\% per tahun tetapi besarnya tingkat investasi ini bukan merupakan jaminan karena realisasinya bergantung pada hasil investasi yang diperoleh. Tetapi untuk ilustrasi ini Tn. Arif tingkat investasi yang real sebesar 4,375\% pada tahun pertama.

Bagi hasil dari keuntungan hasil investasi untuk ilustrasi ini, yaitu 70\%:30\% artinya peserta akan mendapatkan keuntungan hasil investasi sebesar $70 \%$ sedangkan pihak Takaful hanya mendapatkan keuntungan hasil investasi sebesar 30\%. Bagi hasil ini akan dibagikan oleh pihak Takaful kepada Tn. Arif setiap setahun sekali. Berikut perlakuan akuntansi atas ilustrasi kasus di atas:

\section{Pengakuan pada Tahun Pertama}

Pengakuan dalam pencatatan akuntansi untuk tahun pertama dilakukan pada tanggal 30 April 2011 setahun setelah Tn. Arif mengikuti produk ini, yaitu tanggal 30 April 2010. Pada tahun pertama, Tn. Arif hanya bisa mengajukan klaim meninggal dunia baik karena kecelakaan maupun non-kecelakaan dan klaim nilai tunai. Selain itu pada tahun pertamaTn. Arif tidak bisa mengajukan klaim tahapan manfaat karena tahapan manfaatnya belum jatuh tempo. Berikut pengakuan transaksi dana peserta yang terjadi pada tahun pertama.

1) Pada saat penerimaan premi dari peserta

a) Saat adapembagian atasunsur premiyangdibayarkan

(Dr) Kas danBank

(Kr) Kewajiban manfaat polis masadepan

(Kr) Dana pemegang polis unit link
Rp 300.000,00

Rp $103.200,00$

Rp $196.800,00$

b) Saat mencatat biaya polis dan biaya pengelolaan yang diterima pihak Takaful Keluarga dari peserta

(Dr) Kas danBank

Rp 925.000,00

(Kr) Pendapatan premi bruto

Rp 900.000,00 
2) Saat mendapatkan keuntungan dari hasil investasi, tetapi keuntungan tersebut belum dibagikan kepada peserta dan pihak Takaful Keluarga

(Dr) Kas dan Bank

Rp $8.610,00$

(Kr) Pendapatan-hasil investasi

Rp8.610,00

$\operatorname{Rp} \quad 8.610,00(\operatorname{Rp} 196.800,00 \times 100 \% \times 4,375 \%)$

3) Saat keuntungan dari hasil investasi dibagikan kepada peserta sesuai dengan skim bagi hasil, yaitu sebesar $70 \%$

$$
\begin{aligned}
& \text { (Dr) Pendapatan-hasil investasi Rp 6.027,00 } \\
& \text { (Kr) Dana pemegang polis unit link } \quad \mathrm{Rp} \quad 6.027,00 \\
& \text { Rp 6.027,00 (Rp196.800,00x 70\%x4,375\%). }
\end{aligned}
$$

4) Saat peserta mengajukan klaim

a) Apabila mengajukan klaim meninggal dunia karena non-kecelakaan

$$
\begin{array}{lr}
\text { (Dr) Beban klaim dan manfaat } & \text { Rp 10.800.000,00 } \\
\text { (Kr) Hutang klaim } & \text { Rp 10.800.000,00 } \\
\text { Rp 10.800.000,00 (50\%xMTA). }
\end{array}
$$

b) Apabila mengajukan klaim meninggal dunia karena kecelakaan

(Dr) Beban klaim dan manfaat $\quad$ Rp 21.600.000,00

(Kr) Hutang klaim $\quad$ Rp 21.600.000,00

Rp 21.600.000,00 (100\%xMTA).

c) Apabila mengajukan klaim nilai tunai

(Dr) Beban klaim dan manfaat $\quad$ Rp 202.827,00

(Kr)Dana pemegang polis unit link Rp 202.827,00

Rp 202.827,00 (Rp 196.800,00+Rp 6.027,00).

5) Saat pembayaran klaim

a) Pembayaran klaim apabila mengajukan klaim meninggal dunia karena non-kecelakaan
(Dr) Hutang klaim
Rp 10.800.000,00 
(Dr) Danape megang polis unit link Rp 202.827,00

$(\mathrm{Kr})$ Kas dan bank

Rp 11.002.827,00

Maka pencatatan akuntansi saat penerima hibah mendapatkan tahapan manfaat, misalnya tahapan manfaat pada tahun ke-6 (saat masuk TK) adalah:

(1) Saat akan jatuh tempo dana tahapan manfaat

(Dr) Beban klaim dan manfaat

$\operatorname{Rp} 2.160 .000,00$

(Kr) Hutang klaim-tahapan manfaat

$\operatorname{Rp} 2.160 .000,00$

(2) Saat dibayarkan dana tahapan manfaat yang jatuh tempo

tersebut

(Dr) Hutang klaim-tahapan manfaat $\quad \mathrm{Rp} 2.160 .000,00$

(Kr) Kas danBank

$\operatorname{Rp} 2.160 .000,00$

b) Pembayaran klaim apabila mengajukan klaim meninggal dunia karena kecelakaan

(Dr) Hutang klaim

Rp 21.600.000,00

(Dr) Dana pemegang polis unit link $\quad \mathrm{Rp} \quad 202.827,00$

(Kr) Kas dan bank

Rp 21.802.827,00

Maka pencatatan akuntansi saat penerima hibah mendapatkan tahapan manfaat, misalnya tahapan manfaat pada tahunke-6 (saat masuk TK) adalah:

(1) Saat akan jatuh tempo dana tahapan manfaat

(Dr) Beban klaim dan manfaat $\operatorname{Rp} 2.160 .000,00$

(Kr) Hutang klaim-tahapan manfaat Rp 2.160.000,00

(2) Saat dibayarkan dana tahapan manfaat yang jatuh tempo tersebut

(Dr) Hutang klaim-tahapan manfaat $\quad$ Rp 2.160.000,00 
(Kr) Kas

Rp 2.160.000,00

Rp 2.160.000,00 (10\%xRp21.600.000,00).

Dan pencatatan akuntansi saat penerima hibah (anak) mendapatkan beasiswa, misalnya beasiswa pada tahun ke-6 (saat masuk TK) adalah:

(1) Saat akan jatuh tempo beasiswa

(Dr) Beban klaim dan manfaat

Rp 1.080.000,00

(Kr) Hutang klaim-beasiswa

$\operatorname{Rp} 1.080 .000,00$

(2) Saat dibayarkan beasiswa yang jatuh tempo tersebut

(Dr) Hutangklaim-beasiswa

Rp 1.080.000,00

(Kr) Kas danBank

Rp 1.080.000,00

Rp1.080.000,00(50\% x Rp 2.160.000,00).

c) Pembayaran klaim apabila mengajukan klaimnilaitunai

(Dr) Dana pemegang polis unit link

$\operatorname{Rp} 202.827,00$

(Kr) Kas dan Bank

$\operatorname{Rp} 202.827,00$

Rp 202.827,00 (Rp196.800,00 +Rp 6.027,00).

Penyajian Laporan Keuangan pada Tahun Pertama

Berikut penyajian laporan keuangan mengenai transaksi dana peserta pada tahun pertama, yaitu tanggal 30 April 2011 dengan asumsi apabila pada tahun pertama mengajukan klaim meninggal dunia karena nonkecelakaan. 
PT ASURANSI TAKAFUL KELUARGA

Sebagian NERACA

Per 30 April2011

\section{KEWAJIBAN}

Kewajiban kepada pemegang polis

Kewajiban manfaat polis masa depan

Rp $\quad 103.200,00$

Hutang klaim

Rp -

Dana pemegang polis unit link

\begin{tabular}{ll}
$\mathrm{Rp}$ & - \\
\hline $\mathrm{Rp}$ & $103.200,00$ \\
\hline
\end{tabular}

Jumlah Kewajiban kepada Pemegang Polis

PT ASURANSI TAKAFUL KELUARGA

Sebagian LAPORAN LABA RUGI

Per 30 April2011

PENDAPATAN

Pendapatan premi

Premibruto

\begin{tabular}{cc} 
Rp & $900.000,00$ \\
\hline$R p$ & $900.000,00$ \\
$R p$ & $2.583,00$ \\
$R p$ & $25.000,00$ \\
\hline Rp & $\mathbf{9 2 7 . 5 8 3 , 0 0}$ \\
\hline
\end{tabular}

BEBAN

Klaimdan manfaat

Rp 10.800.000,00

Beban klaimdan manfaat polis

Rp 10.800.000,00

JumlahBeban

Rp 10.800.000,00

Sumber: PT Asuransi Takaful Keluarga Cabang Banjarmasin. 


\section{KESIMPULAN}

Takaful Pendidikan merupakan salah satu produk dari PT Asuransi Takaful Keluarga (Jiwa) Cabang Banjarmasin dan merupakan salah satu produk individual yang mengandung unsur saving (tabungan). Takaful Pendidikan juga merupakan produk yang menawarkan tahapan manfaat. Tahapan ini akan diberikan saat penerima hibah (anak) mulai masuk TK, masuk SD, masuk SMP, masuk SMU sampai dengan Perguruan Tinggi. Premi dari peserta tahun pertama akan dialokasikan pada rekening kewajiban manfaat polis masa depan (dana tabarru') dan rekening dana pemegang polis unit link (tabungan peserta).

Bagi hasil untuk peserta tahun pertama dibagikan sesuai dengan skim bagi hasil (mudharabah) dan dicatat dalam rekening dana pemegang polis unit link (bagi hasil). Klaim yang dibayar untuk peserta tahun pertama terdiri dari klaim meninggal dunia baik karena kecelakaan maupun non-kecelakaan, dan klaim nilai tunai. Klaim tersebut akan dibayar oleh pihak Takaful Keluarga sesuai dengan perjanjian yang telah disepakati. Dimana masing-masing jenis klaim tersebut akan mempengaruhi tahapan manfaat yang akan diterima peserta.

\section{DAFTAR PUSTAKA}

Ali, A.M.Hasan. 2004. Asuransi dalam Perspektif Hukum Islam.Edisil. Jakarta: Kencana Prenada Media.

Amir. 2007. Dasar Teori dan Perlakuan Akuntansi PadaAsuransi Syariah Mubarakah.JurnalIntekna. No.1.

Dewi, Gemala. 2004. Aspek-aspek Hukum dalam Perbankan dan Perasuransian Syariah di Indonesia. Jakarta: Kencana Prenada Media.

Ghoni, Abdul dan Erny Arianty. 2007. Akuntansi Asuransi Syariah antara Teori dan Praktik. Edisil. Jakarta: INSCO Consulting.

Hayati, Hanisa dan Nurul Azizah Rakhman. 2007. Studi Komparatif Perlakuan Akuntansi Antara asuransi Jiwa Syariah dan Asuransi Jiwa Konvensional (Studi Kasus pada PT Asuransi Takaful Keluarga dan PTAsuransi Jiwa Sinar Mas).

IAI. 2009. Akuntansi Asuransi Jiwa. Standar Akuntansi Keuangan.J akarta: Salemba Empat.

Juhriah. 2008. Studi Komparatif Perhitungan Klaim Asuransi Dana Pendidikan antara PT Asuransi Takaful dan PT Asuransi Bumiputera Syariah Banjarmasin.

Muhammad. 2005. PengantarAkuntansi Syariah.Edisi2.Jakarta: SalembaEmpat. 
Sholihah, Siti. 2010. Pelaksanaan Asuransi Takaful Dana Pendidikan/Fulnadi di PT Asuransi Takaful Keluarga Cabang Surakarta.

Sula, Muhammad Syakir. 2004. Asuransi Syariah (Life and General) Konsep dan Sistem Operasional. Cetakan Pertama. Jakarta: Gema Insani.

Sugiyono. 2010. Metode Penelitian Pendidikan Pendekatan Kuantitatif, Kualitatif dan $R \& D$. Cetakan Kesebelas. Bandung: Alfabeta. 